\title{
CORRELATION OF LIPID PROFILE AND GLYCEMIA IN ORAL PRECANCEROUS LESION AND CONDITIONS \\ Mujoo S. ${ }^{1 *}$, Shashikant MC. ${ }^{2}$, Dubey A. ${ }^{3}$, Dubey A. ${ }^{4}$
}

\author{
${ }^{1}$ Oral Medicine \& Radiology, College of Dentistry, Jazan University, Jazan, Saudi Arabia. \\ ${ }^{2}$ Oral Medicine \& Radiology, Rungta College of Dental Science, Bhilai, India. \\ ${ }^{3}$ Department of Pedodontics \& Preventive Dentistry, College of Dentistry, Jazan University, Jazan, Saudi \\ Arabia. \\ ${ }^{4}$ Division of Oncology, University of Saskatchewan, Regina, Canada.
}

\begin{abstract}
Background: Lipids are major cell membrane components essential for various biological functions including cell growth and division of normal and malignant tissues. Low lipid values in cancer, precancer lesion and condition may be because of lipid peroxidation as there is greater utilization of lipids including total cholesterol (TC) and triglycerides (TG) for new membrane biogenesis. Cells fulfill these requirements either from circulation or by synthesis through the metabolism.
\end{abstract}

Objective: The present study was aimed at elucidating alteration in serum lipid profile and blood glucose level in Oral Precancerous patients.

Method: A total sample size of 90 subjects were chosen , 30 were diagnosed with leukoplakia and 30 with OSMF and compared with 30 control group. The serum triglycerides were estimated by GPO-PAPA END point Assay method; total cholesterol by CHOD-PAP and HDL cholesterol by PEG-CHOD-PAP, End point assay method with lipid clearing factors. The LDL and VLDL levels were calculated using Friedewalds equation.

Result: This study showed that two parameters TC, TG of lipid profile were significantly reduced in oral Precancerous group cases as compared to age and sex matched healthy controls. There was no significant change in LDL, VLDL, HDL, FBS, and PPBS.

Conclusion: Lower serum TC, TG may indicate with increased risk of precancer occurrence. It may be used as an adjunctive tool in evaluation of oral cancer and pre cancer along with other parameters of biochemical markers.

Keywords: Total Cholesterol, Triglycerides, Lipoproteins, Lipid peroxidation

\section{INTRODUCTION}

Lipids are major cell membrane components essential for various biological functions including cell growth and division of normal and malignant tissues. ${ }^{1}$ Lipids are carried in body fluids in the form of lipoproteins i.e. very low density lipoproteins (VLDL) which are involved in transportation of triglycerides from liver to other cells. Low density lipoproteins (LDL) are responsible for the transportation of cholesterol from liver to the cells and high density lipoproteins (HDL) are involved for the transport of cholesterol from cells to the liver. $^{2}$

*Corresponding author:

Email: : sheetalmujoo@yahoo.co.uk

http://dx.doi.org/10.20530/IJT_33_119-128

ISSN 2320-138X @ 2016
Diabetes mellitus represents a group of metabolic disease and is characterized by hyperglycemia due to a total or relative lack of insulin secretion and insulin resistance or both. ${ }^{3}$ Oral epithelium provides normal protective barrier against carcinogens. In diabetic patients progressive atrophy of oral mucosa occurs due to a decreased rate of salivary secretion and low salivary ph, thereby increasing the possibility of lesions such as glossitis and cheilitis. Loss of normal protective barrier can increase the permeability of the oral mucosa to carcinogens. ${ }^{3}$

In few epidemiological studies increased prevalence of oral premalignant lesions in Diabetic Patients has been reported. ${ }^{3,4}$ Researchers have reported that there is an association between dyslipidemia with different cancers as neoplastic disease is related to new growth, there is greater utilization of lipids for new membrane biogenesis. Cells fulfill these requirements either from 
Table 1. Sex-Wise Distribution of Subjects across Various Groups

\begin{tabular}{lll}
\hline Group & Female & Male \\
\hline Control Group & 3 & 27 \\
& $(10.0 \%)$ & $(90.0 \%)$ \\
Oral Submucous & 4 & 26 \\
Fibrosis Group & $(13.3 \%)$ & $(86.7 \%)$ \\
Leukoplakia Group & $2(6.7 \%)$. & $28(93.3 \%)$ \\
\hline
\end{tabular}

circulation by synthesis through metabolism or from degradation of major lipoprotein faction. ${ }^{1,5}$ Hence present study was carried out to evaluate alteration in serum lipid profile and glycemia in 30 oral submucous fibrosis patients and 30 oral leukoplakia patients and was compared with 30 control groups.

\section{MATERIAL AND METHOD}

Ethics Statement: The studyCo relation in Lipid profile, Glycemia in oral precancerous lesion and conditions was carried in department of oral medicine and oral pathology in Rungta College of Dental Science, Bhilai, India. The study was reviewed and approved by institutional ethical committee and clearance was obtained

Study Design: A total sample size of 90 subjects were chosen out of which 30 were diagnosed with leukoplakia and 30 with OSMF and compared with 30 controlgroup with age and sex matched.

Any subject with systemic disease or taking drugs like corticosteroids was excluded. Subjects between 19-50 years of age who had the habit of tobacco and were diagnosed as leukoplakia and OSMF were included in this study. Patient's general and detailed medical, family and personnel history was recorded and clinical examination was performed.

From each participant $5 \mathrm{ml}$ of fasting (12-14hrs) blood sample was collected and serum was separated. The serum triglycerides were estimated by GPO-PAPA END point Assay method; total cholesterol by CHOD-PAP and HDL cholesterol by PEG-CHOD-PAP, End point assay method with lipid clearing factors. The LDL and VLDL levels were calculated using Friedewalds equation.The data collected was statistically analyzed for TC, TG, LDL, VLDL, HDL, FBS,PPBS levels in leukoplakia, OSMF and control using student t test with SPSS version 15.4

\section{RESULTS}

The sex and age -wise distribution between the control group and study group was not statistically significant.Total cholesterol value and Serum
Table 2. Age-Wise Distribution of the Subjects in Various Groups

\begin{tabular}{lllc}
\hline Group & Mean & $\begin{array}{l}\text { Standard } \\
\text { Deviation }\end{array}$ & Range \\
\hline $\begin{array}{l}\text { Control } \\
\text { Group }\end{array}$ & 37.63 & 7.194 & $21-48$ \\
$\begin{array}{l}\text { Oral } \\
\text { Submucous }\end{array}$ & 29.60 & 9.919 & $18-50$ \\
$\begin{array}{l}\text { Fibrosis } \\
\text { Group }\end{array}$ & & & \\
$\begin{array}{l}\text { Leukoplakia } \\
\text { Group }\end{array}$ & 38.27 & 10.824 & $20-57$ \\
\hline
\end{tabular}

Triglycerides value in both leukoplakia and oral submucous fibrosis group was less than the control group and the difference was statistically significant. Serum HDL Cholesterol level, Serum LDL Cholesterol value, Total VLDL level in both leukoplakia and oral submucous fibrosis group was less than the control group but the difference was not statistically significant.

Fasting Blood Sugar level in oral submucous fibrosis group was similar to control group but leukoplakia group had slight increase and the difference was not statistically significant.Post Prandial Blood Sugar level in oral submucous fibrosis group was similar to control group but leukoplakia group had slight increase and the difference was not statistically significant

Sex-wise distribution of the groups (table 1, graph 1)

Control group $(n=30)$ consisted of 27 males (90.0\%) and 3 females (10.0\%). Leukoplakia group $(n=30)$ consisted of 28 males (93.3\%) and 2 females (6.7\%). Oral submucous fibrosis group $(n=30)$ consisted of 26 males $(86.7 \%)$ and 04 females (13.3\%). The sex distribution between control and study groupwas not statistically significant.

Age-wise distribution of the groups (table 2, graph 2)

The mean age of Control group was 37.63 (range 21- 48 years) and Leukoplakia was 38.27 (range 21-50 years) and Oral submucous fibrosis was 26.90 (range $19-50$ years) and the mean difference between the control group and study group was not statistically significant.

Comparison of lipid profile, blood sugar level in osmf and leukoplakia group with the control group

Serum Total Cholesterol level (Table 3, Graph 3) The mean Total Cholesterol level in Control group was $180.40+/-26.78$, Leukoplakia group was 
Graph1. Sex-wise Distribution of subjects across various groups

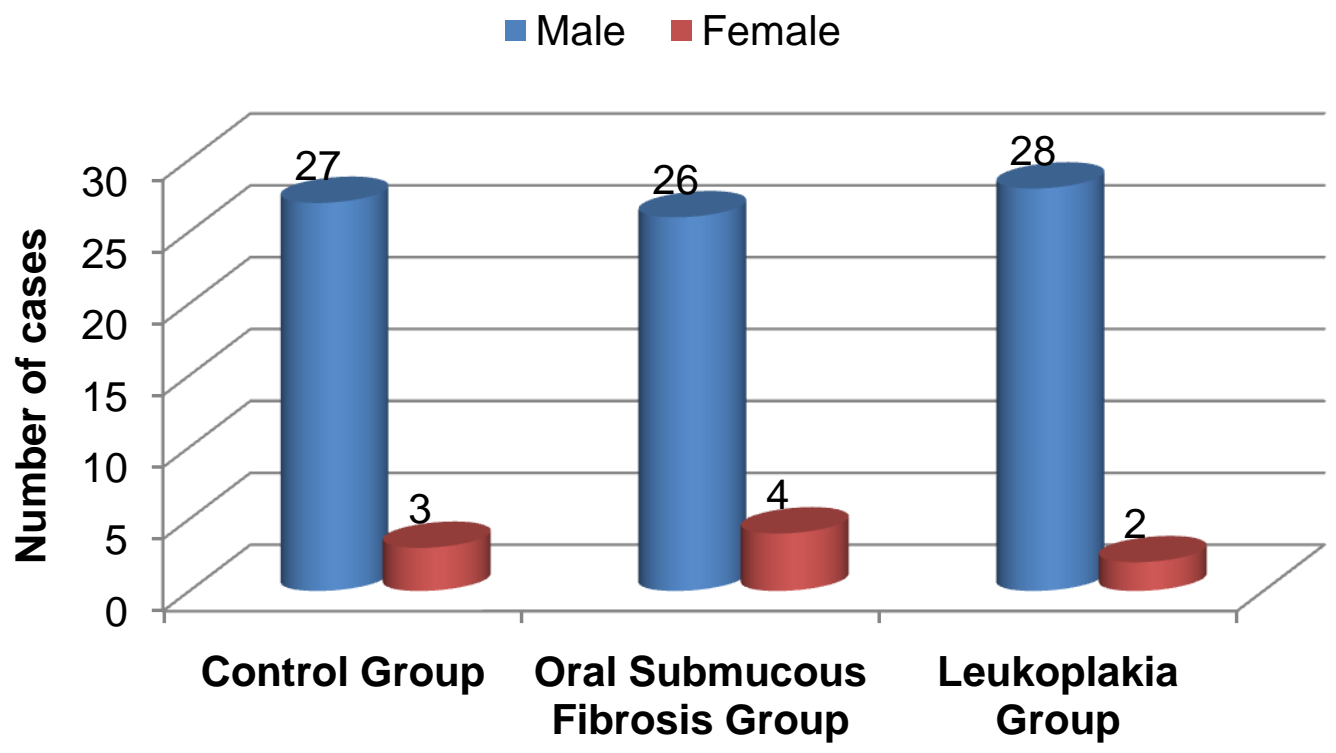

$167.07+/-23.68$ and Oral submucous fibrosis group was $164.37+/-26.78$.

Total cholesterol value in both leukoplakia and oral submucous fibrosis group was less than the control group and the difference was statistically significant ( $P$ value $<0.05)$.

\section{Serum Triglycerides level (Table 3, Graph 4)}

The mean Serum Triglycerides level in Control group was $164.80+/-27.766$, Leukoplakia group was $160.40+/-32.193$ and Oral submucous fibrosis group was 145.30+/- 32.094.

Serum Triglycerides value in both leukoplakia and oral submucous fibrosis group was less than the control group and the difference was statistically significant ( $P$ value $<0.05$ ).

Serum HDL Cholesterol level (Table 3, Graph 5)

The mean Serum HDL Cholesterol level in Control group was $62.97+/-11.705$, Leukoplakia group was $63.50+/-12.054$ and Oral submucous fibrosis group was 63.43 +/- 10.013. Serum HDL Cholesterol level value in both leukoplakia and oral submucous fibrosis group was less than the control group but the difference was not statistically significant ( $P$ value $>0.05$ ).

Serum LDL Cholesterol level (Table 3, Graph 6) The mean Serum LDL Cholesterol level in Control group was 74.20+/- 21.922, Leukoplakia group was

\section{Graph 2. Age-wise distribution of the group}

\section{- Control Group $\quad$ Oral Submucous Fibrosis Group — Leukoplakia Group}

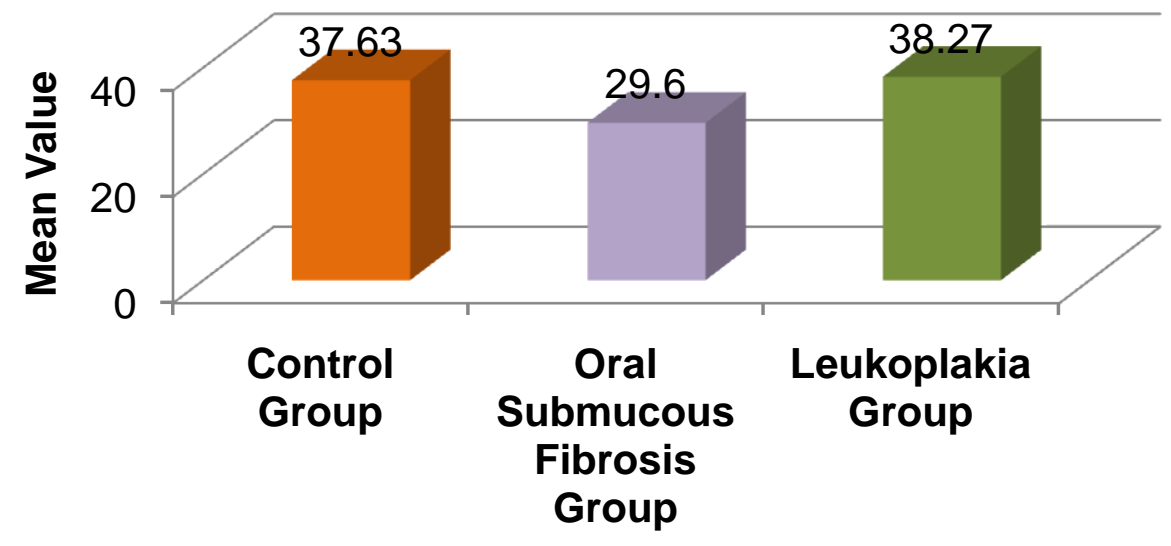


Intornatinnal Inırnal nf Thoranoutir Annliratinnc V/nlımo 22 Jn16 119_128

Table 3. Comparison of Mean Serum Lipid profile, Glycemia in OSMF, Leukoplakia and Control Group

\begin{tabular}{|c|c|c|c|}
\hline & Control & OSMF & Leukoplakia \\
\hline Total Cholesterol & $180.40+/-26.718$ & $\begin{array}{l}164.37+/-26.78 \\
P=.024\end{array}$ & $\begin{array}{l}167.07+/-23.68 \\
P=.045\end{array}$ \\
\hline Triglyceride & $164.80+/-27.766$ & $\begin{array}{l}145.30+/-32.094 \\
P=.015\end{array}$ & $\begin{array}{l}160.40+/-32.193 \\
P=.573\end{array}$ \\
\hline HDLC & $62.97+/-11.705$ & $\begin{array}{l}63.43+/-10.013 \\
P=.869\end{array}$ & $\begin{array}{l}63.50+/-12.054 \\
P=.863\end{array}$ \\
\hline LDLC & $74.20+/-21.922$ & $\begin{array}{l}66.40+/-39.013 \\
P=.344\end{array}$ & $\begin{array}{l}67.70+/-27.122 \\
P=.312\end{array}$ \\
\hline VLDLC & $35.77+/-13.888$ & $\begin{array}{l}31.17+/-12.895 \\
P=.189\end{array}$ & $\begin{array}{l}35.33+/-14.404 \\
P=.906\end{array}$ \\
\hline FBS & $80.87+/-16.083$ & $\begin{array}{l}84.57+/-9.058 \\
P=0.277\end{array}$ & $\begin{array}{l}89.53+/-30.051 \\
P=0.169\end{array}$ \\
\hline PPBS & $106.17+/-18.166$ & $\begin{array}{l}113.33+/-18.631 \\
P=0.137\end{array}$ & $\begin{array}{l}120.63+/-33.458 \\
P=0.042\end{array}$ \\
\hline
\end{tabular}

$P$ value $<0.05$ is statistically significant.

$P$ value $>0.05$ is statistically insignificant

$67.70+/-27.122$ and Oral submucous fibrosis group was $66.40+/-39.013$.

Serum LDL Cholesterol level in both leukoplakia and oral submucous fibrosis group was less than the control group but the difference was not statistically significant ( $P$ value $>0.05$ ).

\section{Serum VLDL Cholesterol level (Table 3, Graph 7)}

The mean Serum VLDL Cholesterol level in Control group was $35.77+/-13.888$, Leukoplakia group was $35.33+/-14.404$ and Oral submucous fibrosis group was $31.17+/-12.895$.

Total VLDL level in both leukoplakia and oral submucous fibrosis group was less than the control group but the difference was not statistically significant ( $P$ value $>0.05$ ).

Fasting Blood Sugar level (Table 3, Graph 8)

The mean Fasting Blood Sugar level in Control group was $80.87+/-16.083$, Leukoplakia group was $89.53+/-30.051$ and Oral submucous fibrosis group was $84.57+/-9.058$.

Fasting Blood Sugar level in oral submucous fibrosis group was similar to control group but leukoplakia group had slight increase and the difference was not statistically significant ( $P$ value $>0.05$ ).

Post Prandial Blood Sugar level (Table 3, Graph 9) Post Prandial Blood Sugar level in oral submucous fibrosis group was similar to control group but leukoplakia group had slight increase and the difference was not statistically significant ( $P$ value $>0.05$ ).
The mean Post Prandial Blood Sugar level in Control group was 106.17+/- 18.166, Leukoplakia group was $120.63+/-33.458$ and Oral submucous fibrosis group was $113.33+$ /- 18.631 .

\section{DISCUSSION}

Pre cancer and cancer of the oral cavity presents challenging and unresolved problem for the human population. Patients with oral precancerous conditions have also been reported to show a significant tendency to develop cancer. The habit of tobacco consumption is a known etiological factor for the development of precancerous diseases and oral cancer. $6,7,8$

Cancer of the oral cavity constitutes about 3-4\% of all cancers in western industrialized countries, mainly affects middle aged people, and is more common in men than in women. In India where the habits of chewing tobacco with betel nut, reverse smoking and alcohol usage are common, there is a striking incidence of oral cancer which accounts for as many as $30-40 \%$ of all cancers. ${ }^{9}$

Increasing incidence of oral cancer and pre cancer in Indian population necessitates in depth probing of various etiological and contributory factors for its early diagnosis and prognosis.

In the present study, mean Total Cholesterol level was significantly $(p>0.05)$ reduced in oral submucous fibrosis and leukoplakia group when compared with the control group. (Table 3)

Chalkoo $\mathrm{AH}$ et $\mathrm{al}^{10}$ andNayak Pet al ${ }^{5}$ Lohe et al, ${ }^{11}$ Patel et al, ${ }^{1}$ Chawda $\mathrm{JG}^{12}$ Jainfound a significant decrease in serum total cholesterol level in oral precancer group when compared with the control 
International Journal of Therapeutic Applications, Volume 33, 2016, 119-128

Graph 3. Comparison of Total Cholesterol in three groups

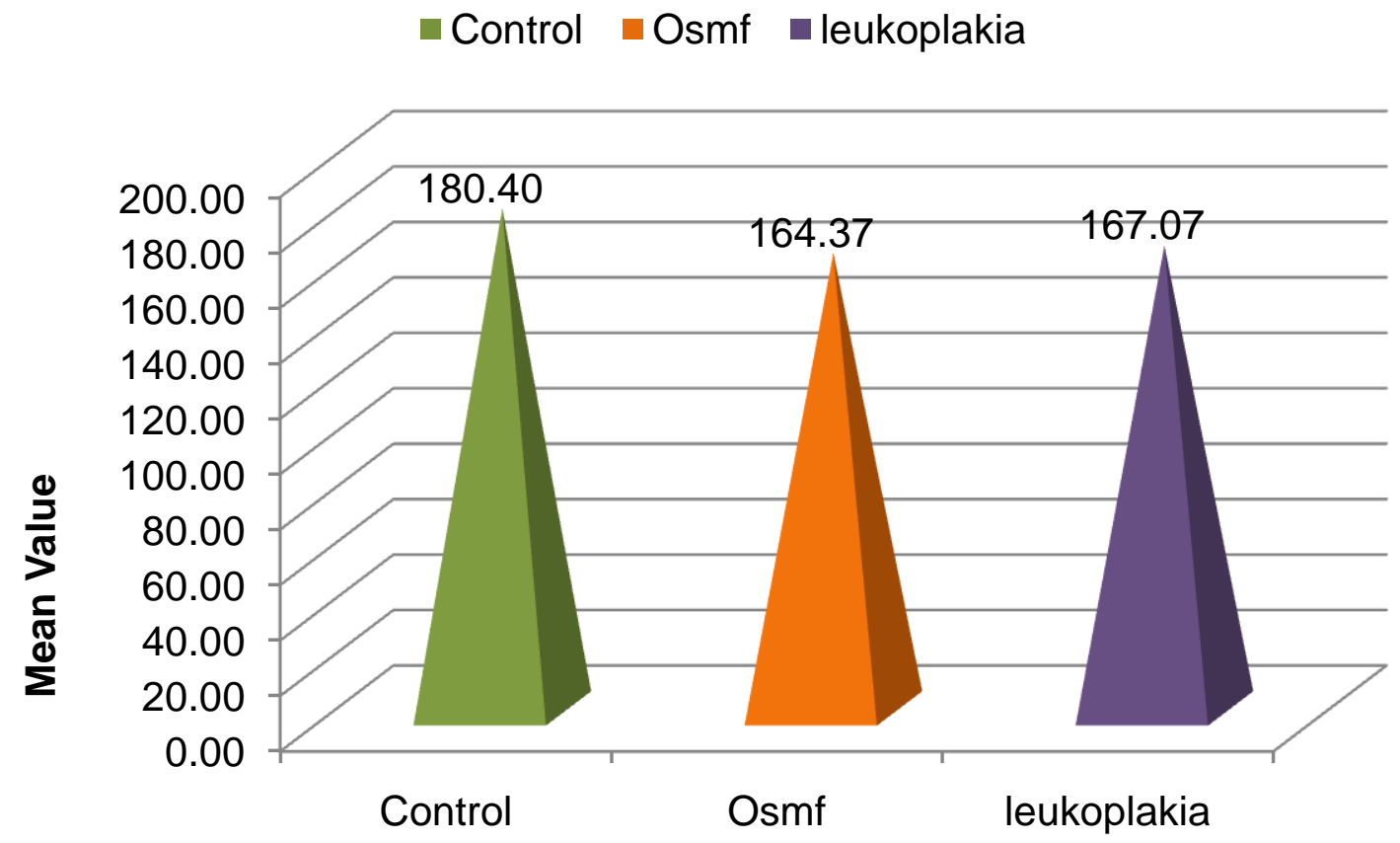

group which was consistent with the results of our Santiago et $\mathrm{al}^{14}$, Meenakshisundaram Ret al, study. Mehrotra et al, Gupta BK et alKhurana et aland

Graph 4. Comparison of Triglycerides in three groups



A similar study was performed by Qadir $\mathrm{Ml}$ et $\mathrm{al}^{13}$ in sarcoma patients and reported a decrease in serum cholesterol level when compared with the control group.
Zheng $\mathrm{W}$ et al, found a raised total cholesterol in precancerous group as compared to controls 
Graph 5. Comparison of HDL-C in three groups

\section{- Control $\quad$ Osmf $\quad$ leukoplakia}

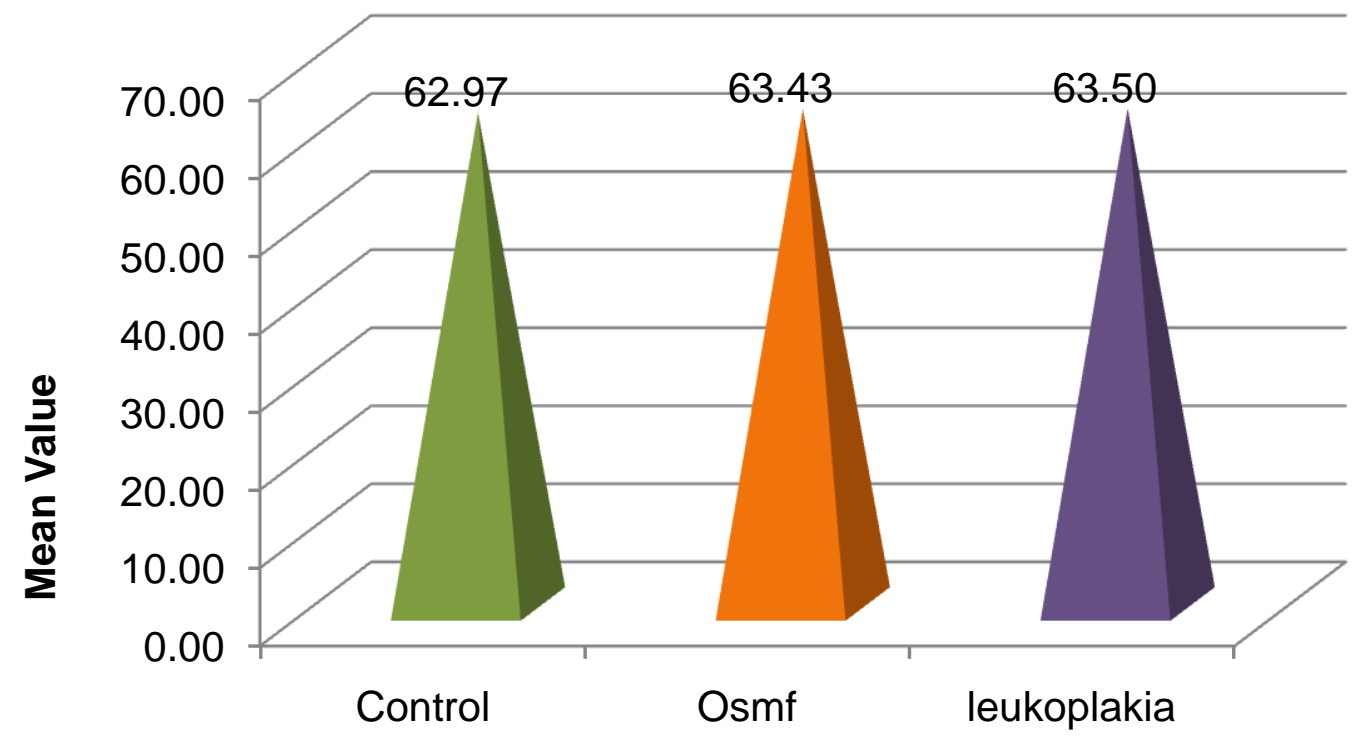

which was not consistent with our findings.

The result of present study showed that mean Serum Triglycerides were significantly reduced $(P$ value $<0.05$ ) in oral submucous fibrosis and leukoplakia group when compared with the control group. (Table 3)

Schatzkin A et al, ${ }^{19}$ and Qadir $\mathrm{Ml}$ et al ${ }^{13}$ reported a decrease in serum triglyceride level in oral precancerous group when compared with control which was consistent with the findings of our present study.

Gupta BK et al, ${ }^{20}$ Meenakshisundaram $\mathrm{R}$ et al, ${ }^{15}$ Raste AS and Naik PP, ${ }^{21}$ Mehrotra $R$ et al, ${ }^{16}$ found araised triglyceride level in oral cancer and precancer group which was inconsistent with the findings of present study.
In the present study mean Serum LDL cholesterol level was reduced in oral submucous fibrosis and leukoplakia group when compared with the control group but the difference was not statistically significant. (Table 3) which was consistent with the studies conducted by Chalkoo $\mathrm{AH}$ et $\mathrm{al}^{10}{ }^{10}$ Nayak $\mathrm{P}$ et $\mathrm{al}^{5}$ and Santiago SA et $\mathrm{al}^{22}$. Gupta BK et al, ${ }^{20}$ Meenakshisundaram R et al ${ }^{15}$ and Mehrotra $\mathrm{R}$ et $\mathrm{al}^{16}$ found raised LDL cholesterol level in oral precancer and cancer patients which The result of present study showed that mean Serum VLDL cholesterol level was reduced in oral submucous fibrosis and leukoplakia group when compared with the control group but the difference was not statistically significant (Table 3 ) which was consistent with the findings obtained by

Graph 6. Comparison of LDL-C in three groups

- Control = Osmf - leukoplakia

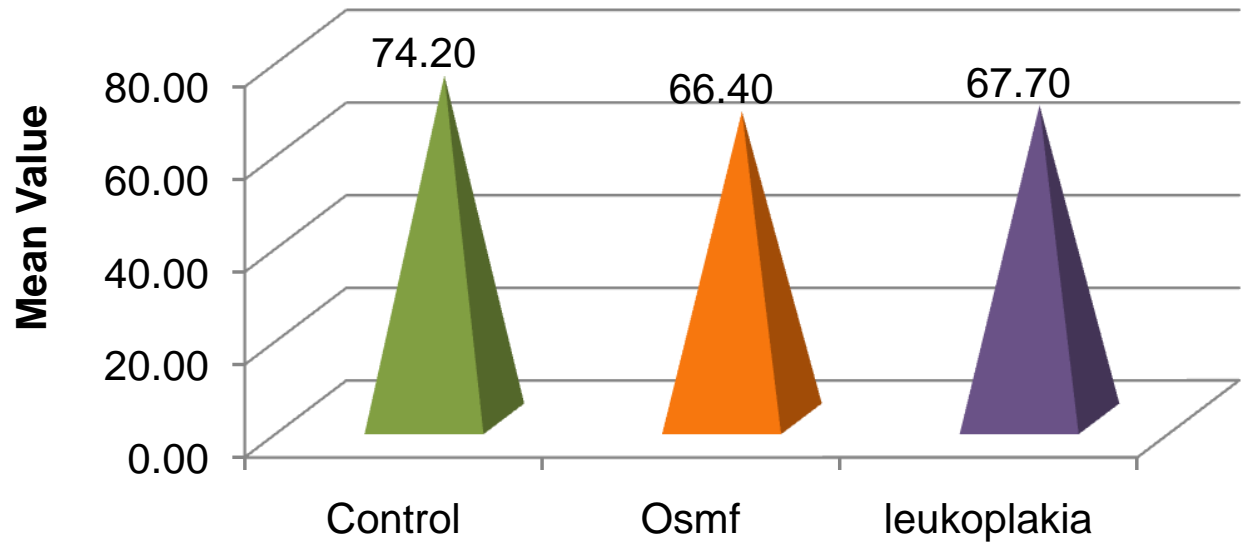




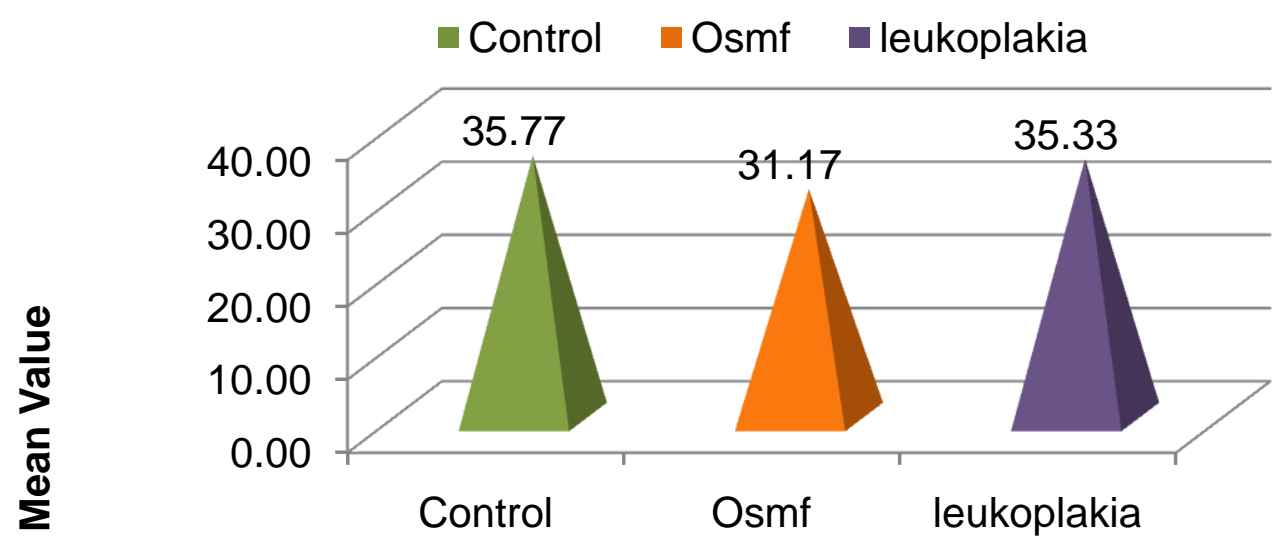

Graph 8. Comparison of FBS in three groups

- Control $\quad$ Osmf -leukoplakia

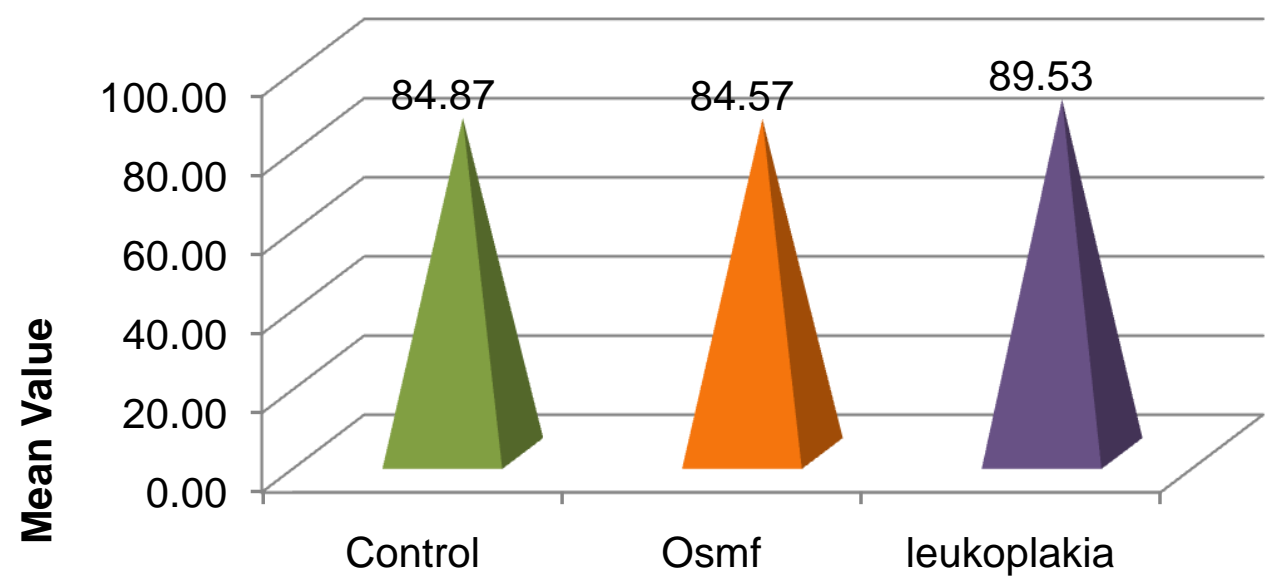

Chalkoo $\mathrm{AH}$ et al, ${ }^{10}$ Nayak et $\mathrm{al}^{5}$ and Schatzkin et al, ${ }^{19}$ Goyal $S$ et al. ${ }^{23}$

Santiago SA et al, ${ }^{22}$ Gupta BK et al, ${ }^{20}$ Meenakshisundaram $R$ et al, ${ }^{15}$ Nayak $P$ etal ${ }^{5}$ found a decrease in $\mathrm{HDL}-\mathrm{C}$ level in oral pre cancer which was consistent with the results of was inconsistent with the results obtained in the present study.

The result of present study showed that mean Serum HDL cholesterol level was reduced in oral submucous fibrosis and leukoplakia group when compared with the control group but the difference was not statistically significant.(Table 3) present study.

Chalkoo A.H et al $^{10}$ found increase in serum HDL- C level in oral submucous fibrosis patients which was not consistent with the results of present study.

Mehrotra Ret al $^{16}$ found a significant increase in serum VLDL level in oral pracanerous group when compared with control group which was inconsistent with the results obtained in the present study. The result of present study showed that Fasting and Post Prandial blood sugar level didn't alter in oral submucous fibrosis and leukoplakia group when compared with the control group which was consistent with the results obtained by Dikshit RP et $\mathrm{al}^{4}$ andSaini $\mathrm{R}$ et al. ${ }^{24}$ Meisel Pet $\mathrm{al}^{25}$ and Albrecht $\mathrm{M}$ et $\mathrm{al}^{26}$ found that the prevalence of leukoplakia in diabetes is significantly high which was inconsistent with the results of present study.

The possibility of having variation in serum lipid profile of precancer group when compared with the control group can be explained by the following reasons. $^{27}$

1. Newly forming and rapidly proliferating malignant cells need many basic components such as lipids well above the normal physiological limits leading to diminished lipid stores.

2. Tobacco induces generation of free radicals and reactive oxygen species responsible for higher rate of oxidation/ peroxidation of poly unsaturated fatty acids (PUFA), in turn leading to increased utilization of lipids. 
3. Association of hypolipidemia with cancer may be secondary to other factors.

4. May be due to increased membrane permeability to carcinogens induced by Trans fatty acids.

5. May be due to anti-oxidant vitamin therapy.

Lipid peroxidation may play an important role in cancer development as lipid peroxidationproduct, malondialdehyde, may cross-link deoxyribonucleic acid adenine and

the required frequency of habit which can represent the status and the patients in the precancer group in our study, as a group, might represent patients who are in the initial stages of carcinogenicity and mutagenicity inmammalian cells. Lipid peroxidation may be induced by tabacco carcinogens that are known to produce reactive oxygen species and lipid peroxides.The possibility of not having any significant variation in serum HDL, VLDL, LDL,,FBS, PPBS of precancer group when compared with the control group can be explained by the following reasons- the subjects in the precancer group might not have the long period of time of habitusage Lower cholesterol levels before detection of carcinoma may be due to underlying carcinoma process and FBS, and PPBS in the present study. This might be because the oral precancer patients might be at initial stages of precancer and have not caused degradation of major lipoprotein fractions like

\section{Graph 9. Comparison of PPBS in three groups}

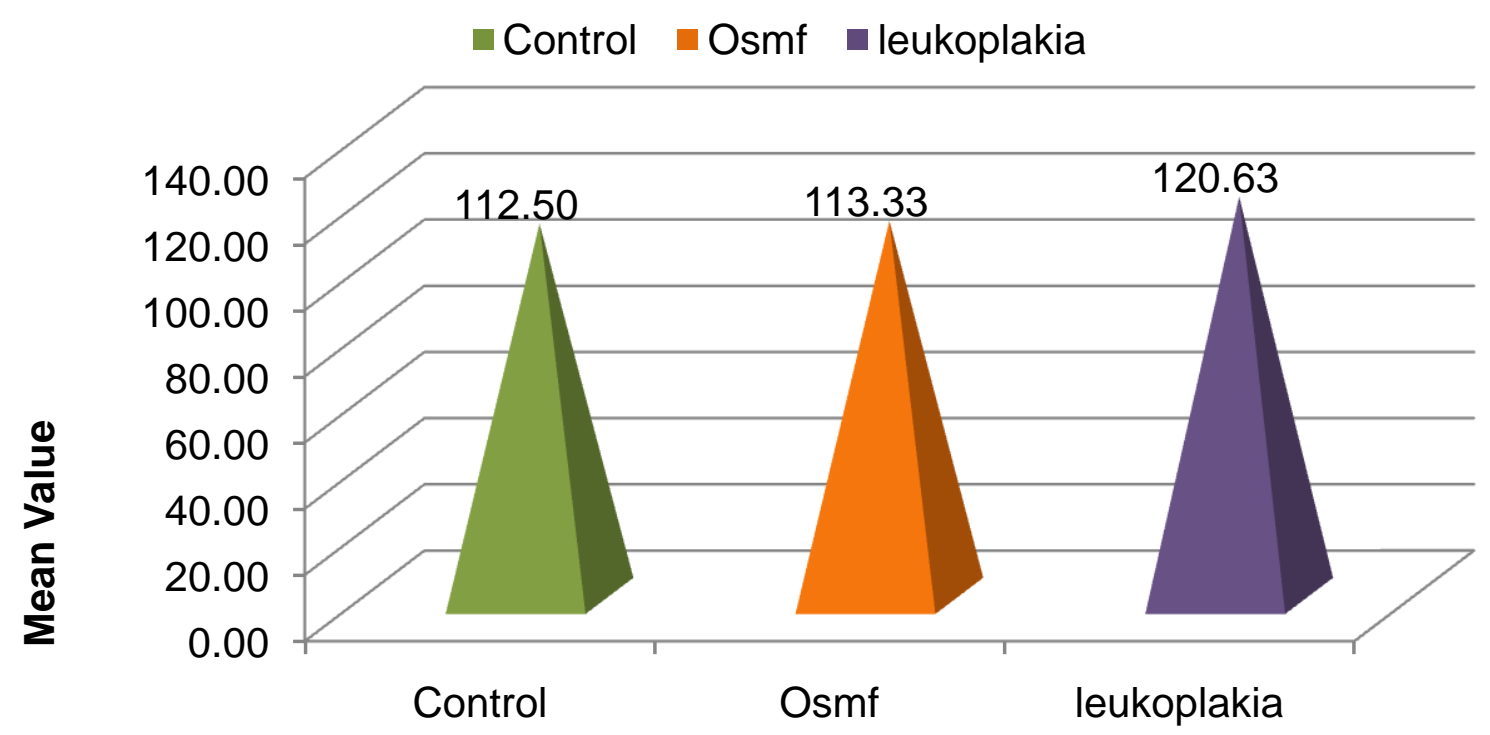

precancer, which might not have caused the lipid changes in the blood. ${ }^{24,27}$

The present study was aimed at elucidating alteration in serum lipid profile and blood glucose level in Oral Precancerous patients. This study showed that 2 parameters TC, TG of lipid profile were significantly reduced in oral Precancerous group cases as compared to age and sex matched healthy controls. Low lipid values in serum may be because of lipid peroxidation, there is greater utilization of lipids including TC, TG for new membrane biogenesis. Cells fulfill these requirements either from circulation or by synthesis through the metabolism. So, lower serum TC, TG may indicate with increased risk of precancer occurrence.

There was no significant change in LDL, VLDL, HDL, cytosine. This may in theory contribute to
VLDL, HDL, and LDL and also has not affected the glycemic levels of patients.

\section{CONCLUSION}

Lipid profile and blood sugar level estimation can be used as an adjunctive tool in evaluation of oral cancer and pre cancer along with other parameters of biochemical markers.Further longitudinal studies with larger sample size and long term follow up of pre cancer cases with periodic estimation of lipid profile and glycemia would be needed to establish correlation between transformations from a precancerous state to malignancy.

\section{REFERENCES}

1. Raval G, Patel D, Parekh L, Patel J, Shah M, Patel P. Evaluation of serum sialic acid, sialyltransferase and sialoproteins in oral cavity cancer. Oral Diseases; 2003 May;9(3):119-28. Available from: 
http://dx.doi.org/10.1034/j.16010825.2003.01795.x

2. Janbaz K, Qadir M, Younas F, Malik S. Future strategies in treatment of parkinson's disease. Journal of College of Medical Sciences-Nepal; 2012 Aug 23;7(2). Available from: http://dx.doi.org/10.3126/jemsn.v7i2.6687

3. Govila V, Govila S, Gupta S, Singh D. Periodontitis: An Emerging Risk Factor for Diabetes. Internat Journ of Oral Heal; 2015;1(4):182. Available from: http://dx.doi.org/10.5958/2395-499x.2015.00008.8

4. Dkshit RP, Ramadas K, Hashibe M, Thomas G, Somanathan T, Sankaranarayanan R. Association between diabetes mellitus and pre-malignant oral diseases: A cross sectional study in Kerala, India. Int J Cancer; 2006 Jan 15;118(2):453-7. Available from: http://dx.doi.org/10.1002/ijc.21345

5. Chimowitz MI, Furlan AJ, Nayak S, Sila, MD CA. Mechanism of stroke in patients taking aspirin. Neurology ;40(11):1682-1682. Available from: http://dx.doi.org/10.1212/wnl.40.11.1682

6. Lewis MAO. Burket's Oral Medicine. Diagnosis and Treatment, 10th edn. Journal of Orthodontics; 2003 Dec;30(4):346-346. Available from: http://dx.doi.org/10.1093/ortho/30.4.346

7. Lewis MAO. Burket's Oral Medicine. Diagnosis and Treatment, 10th edn. Journal of Orthodontics;30(4):346-346. Available from: http://dx.doi.org/10.1093/ortho/30.4.346

8. Pujari R, N. V. Mast Cell Density in Oral Submucous Fibrosis: A Possible Role in Pathogenesis. IJHS;7(1):23-9. Available from: http://dx.doi.org/10.12816/0006017

9. Prabhakara G. Short Textbook of Preventive and Social Medicine. Jaypee Brothers Medical ; Available from: http://dx.doi.org/10.5005/ip/books/11257

10. Hussain Chalkoo A, Singh Risam S, Farooq R. A Study on Alterations in Plasma Lipid Profile Patterns in OSMF Patients. Kailasam S, editor. Journal of Indian Academy of Oral Medicine and Radiology; 2011;23:36-8. Available from: http://dx.doi.org/10.5005/ip-journals-10011-1087

11. Lohe VK, Degwekar SS, Bhowate RR, Kadu RP, Dangore SB. Evaluation of correlation of serum lipid profile in patients with oral cancer and precancer and its association with tobacco ; 2010 Feb;39(2):141-8. Available from: http://dx.doi.org/10.1111/j.16000714.2009.00828.x

12.

13. Chawda J, Jain S, Patel H, Chaduvula N, Patel K. The relationship between serum lipid levels and the risk of oral cancer. Indian Journal of Medical and Paediatric Oncology; 2011;32(1):34. Available from: http://dx.doi.org/10.4103/0971-5851.81888

14. Janbaz K, Qadir M, Younas F, Malik S. Future strategies in treatment of parkinson's disease. Journal of College of Medical Sciences-Nepal ; 2012 Aug 23;7(2). Available from: http://dx.doi.org/10.3126/jemsn.v7i2.6687

15. Arias-Santiago $S$, Buendía-Eisman A, AneirosFernández J, Girón-Prieto MS, Gutiérrez-Salmerón
MT, Mellado VG, et al. Cardiovascular Risk Factors in Patients with Lichen Planus. The American Journal of Medicine; 2011 Jun;124(6):543-8. Available from: http://dx.doi.org/10.1016/i.amimed.2010.12.025

16. Meenakshisundaram R, Rajendiran C, Thirumalaikolundusubramanian P. Lipid and lipoprotein profiles among middle aged male smokers: a study from southern India. Tob Induced Dis ; 2010;8(1):11. Available from: http://dx.doi.org/10.1186/1617-9625-8-11

17. Mehrotra R, Pandya S, Chaudhary A, Singh $H$, Jaiswal $R$, Singh $M$, et al. Lipid profile in oral submucous fibrosis. Lipids in Health and Disease ; 2009;8(1):29. Available from: http://dx.doi.org/10.1186/1476-511x-8-29

18. Yadav BK, Bade AR, Singh J, Jha B. Comparative study of lipid profile in smokers, tobacco chewers and diabetic patients. Journal of Institute of Medicine; 2007 Jan 5;27(3). Available from: http://dx.doi.org/10.3126/joim.v27i3.416

19. Helzlsouer KJ, Alberg AJ, Norkus EP, Morris JS, Hoffman SC, Comstock GW. Prospective Study of Serum Micronutrients and Ovarian Cancer. JNCl Journal of the National Cancer Institute; 1996 Jan 3;88(1):32-7. Available from: http://dx.doi.org/10.1093/inci/88.1.32

20. Schatzkin A, Jones DY, Hoover RN, Taylor PR, Brinton LA, Ziegler RG, et al. Alcohol Consumption and Breast Cancer in the Epidemiologic Follow-up Study of the First National Health and Nutrition Examination Survey. New England Journal of Medicine; 1987 May 7;316(19):1169-73. Available from:

http://dx.doi.org/10.1056/nejm198705073161901

21. Gupta R, Suchday S, Sharma K, Gupta B, Achari V, Singh J, et al. PM316 Depression, Chronic Stress, Or Both, And Cardiovascular Risk Factors: A Cross Sectional Study Among Urban Subjects In India. Global Heart; 2014 Mar;9(1):e126. Available from: http://dx.doi.org/10.1016/i.gheart.2014.03.1675

22. Raste AS, Naik PP. Clinical significance of lipid profile in cancer patients. Indian J Med Sci 2000; 54:435-41.

23. Arias-Santiago $S$, Buendía-Eisman A, AneirosFernández J, Girón-Prieto MS, Gutiérrez-Salmerón MT, Mellado VG, et al. Cardiovascular Risk Factors in Patients with Lichen Planus. The American Journal of Medicine; 2011 Jun;124(6):543-8. Available from: http://dx.doi.org/10.1016/i.amimed.2010.12.025

24. Lohe VK, Degwekar SS, Bhowate RR, Kadu RP, Dangore SB. Evaluation of correlation of serum lipid profile in patients with oral cancer and precancer and its association with tobacco abuse. Journal of Oral Pathology \& Medicine; 2010 Feb;39(2):141-8. Available from: http://dx.doi.org/10.1111/j.1600$\underline{0714.2009 .00828 . x}$

25. Saini R, Al-Maweri SA, Saini D, Ismail NM, Ismail AR. Oral mucosal lesions in non oral habit diabetic patients and association of diabetes mellitus with oral precancerous lesions. Diabetes Research and Clinical Practice; 2010 Sep;89(3):320-6. Available 
International Journal of Therapeutic Applications, Volume 33, 2016, 119-128

from:

http://dx.doi.org/10.1016/i.diabres.2010.04.016

26. Meisel P, Dau M, Sumnig W, Holtfreter B, Houshmand $M$, Nauck $M$, et al. Association Between Glycemia, Serum Lipoproteins, and the Risk of Oral Leukoplakia: The population-based Study of Health in Pomerania (SHIP). Diabetes Care ; 2010 Mar 9;33(6):1230-2. Available from: http://dx.doi.org/10.2337/dc09-1262

27. Albrecht M, Banoczy J, Dinya E, Tamas G. Occurrence of oral leukoplakia and lichen planus in diabetes mellitus. Journal of Oral Pathology and Medicine; 1992 Sep;21(8):364-6. Available from: http://dx.doi.org/10.1111/j.16000714.1992.tb01366.x

28. Kumar P, Augustine J, Urs A, Arora S, Gupta S, Mohanty V. Serum lipid profile in oral cancer and leukoplakia: Correlation with tobacco abuse and histological grading. Journal of Cancer Research and Therapeutics ; 2012;8(3):384. Available from: http://dx.doi.org/10.4103/0973-1482.103517 